\title{
Anthropic effects on hydrochemical characteristics of the Valle de Toluca aquifer (central Mexico)
}

\author{
M. V. Esteller • J. M. Andreu
}

\begin{abstract}
The Valle de Toluca aquifer, located in the Highlands of Mexico, is subject to intensive exploitation to meet the water demand in the valley, as well as for part of Mexico City. This intensive exploitation has produced a decline in groundwater level, land subsidence problems and a decrease in river and spring flows. This study is aimed at determining the extent to which the intensive groundwater abstraction is able to affect and modify the chemical characteristics of the water, using statistical techniques and historical data on the main physicochemical parameters. Some changes in the chemical characteristics have been verified; initial water abstractions were mainly derived from a local flow zone (rainwater recharge and lateral flows from other aquifers), but currently the chemical characteristics are those of a regional flow zone, revealed by waters of sodium bicarbonate type. An increase in nitrate content has also occurred, although only occasionally is the limit for potable water $\left(50 \mathrm{mg} \mathrm{NO}_{3}^{-} \mathrm{L}^{-1}\right)$ exceeded.
\end{abstract}

Résumé L'aquifère Valle de Toluca, localisé dans les Hautes Terres du Mexique, est sujet à l'exploitation intensive pour combler la demande importante en eau dans la vallée et dans une partie de Mexico. Cette exploitation intensive a causé une baisse importante des niveaux piézométriques, des problèmes d'affaissement et de baisse de débits des sources et des rivières. Cette étude a pour objectif de déterminé la limite jusqu'à laquelle l'exploi-

Received: 26 August 2002 / Accepted: 15 September 2004 Published online: 13 January 2005

(C) Springer-Verlag 2005

M. V. Esteller $(\bullet)$

Centro Interamericano de Recursos del Agua -

Facultad de Ingeniería,

Universidad Autónoma del Estado de México,

Cerro Coatepec S/N C.U., 50130 Toluca, Mexico

e-mail: esteller@uaemex.mx

Tel.: +52-722-2965550

Fax: +52-722-2965551

J. M. Andreu

Dpto. Ciencias de la Tierra y del Medio Ambiente.

Universidad de Alicante,

P.O. Box 99,

03080 Alicante, Spain tation intensive pourra affecté et modifié les caractéristiques chimiques de l'eau, en utilisant des techniques statistiques et des données historiques des principaux paramètres physico-chimiques. Certains changements des caractéristiques chimiques ont été vérifiés ; les premières eaux captées ont été compensées par d'autres zones d'alimentation (recharge par les eaux de pluie et écoulements latéraux venant d'autres aquifères), mais couramment les caractéristiques chimiques sont bien ceux de la zone d'écoulement régional, à faciès sodi bicarbonaté. Une augmentation des concentrations en nitrate est également mis en valeur, néanmoins la limite de potabilité $(50 \mathrm{mg} / \mathrm{l})$ est rarement dépassée.

Resumen El acuífero del Valle de Toluca, localizado en el Altiplano Mexicano, se encuentra sometido a una intensa explotación para cubrir las necesidades de agua en el propio valle, así como parte de las de Ciudad de México. Los altos niveles de explotación han provocado el descenso del nivel piezométrico, problemas de subsidencia, disminución de caudales en ríos y desecación de manantiales. Este estudio pretender determinar en qué grado esta intensiva extracción del agua subterránea es capaz de afectar y modificar el quimismo del agua. Para ello se han empleado técnicas estadísticas y datos históricos de los principales parámetros físico-químicos. Se ha podido comprobar que existen algunos cambios en el quimismo, ya que, inicialmente, el agua extraída del acuífero estaba ligada en gran medida a un flujo local (recarga por agua de lluvia y por alimentación lateral desde otros acuíferos) mientras que ahora el quimismo es característico de un flujo regional, puesto de manifiesto por aguas de tipo bicarbonatado sódico. Adicionalmente, también se ha producido un aumento del contenido de nitratos, aunque sólo de forma ocasional se sobrepasa el límite para agua potable $\left(50 \mathrm{mg} \mathrm{NO}_{3}^{-} \mathrm{L}^{-1}\right)$.

Keywords Groundwater management .

Over-abstraction $\cdot$ Hydrochemistry $\cdot$ Pollution $\cdot$ Mexico

\section{Introduction}

The Valle de Toluca is located in a region known as the Highlands of Mexico, in the center of the country (Fig. 1), comprising an area of approximately $900 \mathrm{~km}^{2}$. This valley 


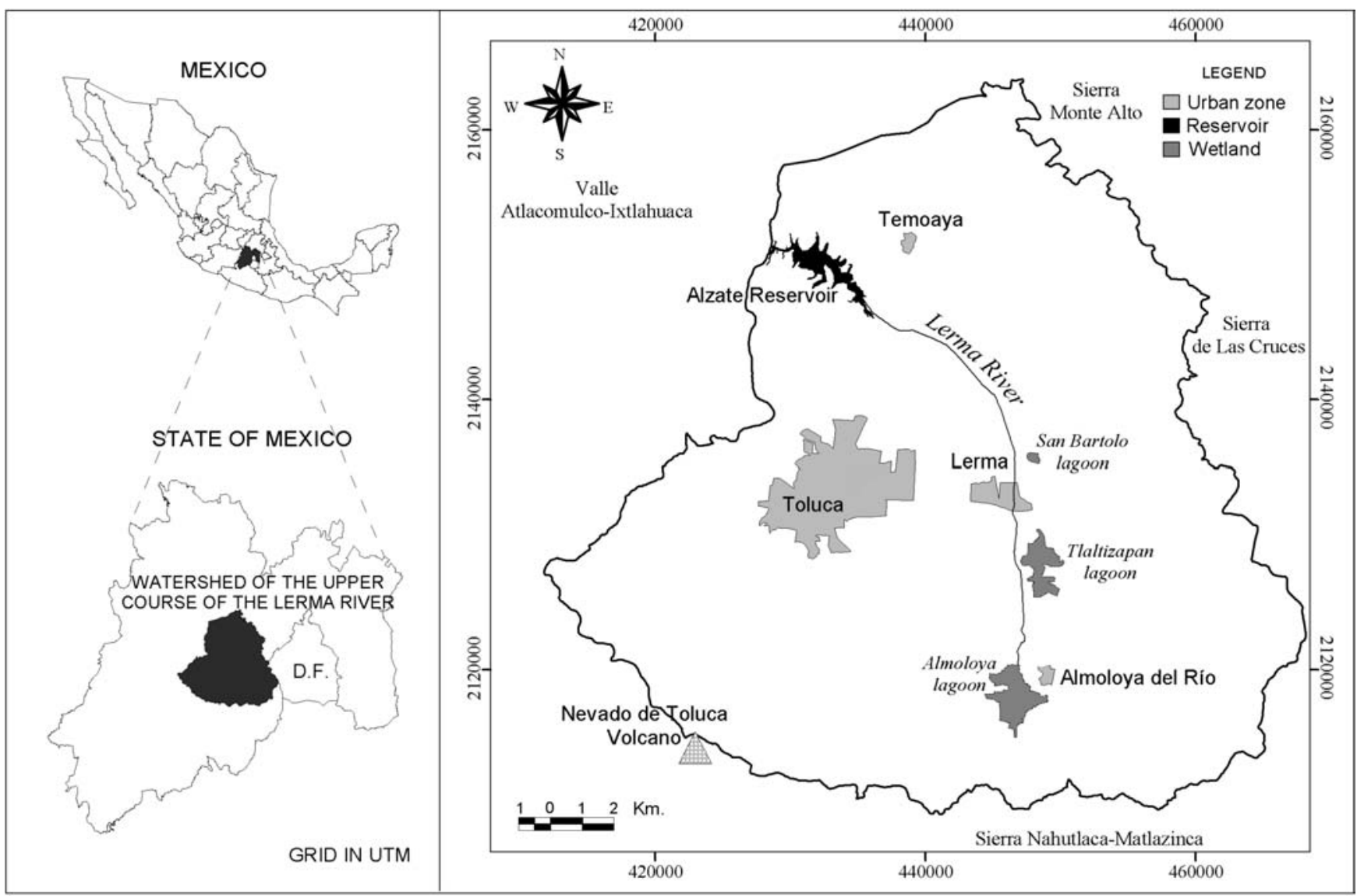

Fig. 1 Location of the Valle de Toluca aquifer (upper course of the Lerma River), Mexico

is an important center for industry (3,438 companies) and agriculture $(56 \%$ of the surface is agricultural soil). This fact has led to an increase in the number of inhabitants over the course of the last four decades, especially after the Mexico City earthquake (1985) that caused many industries to settle in the valley. According to the last census (2000), population in the valley reached 1.6 million inhabitants, with $65 \%$ living in urban areas and $35 \%$ in rural areas.

This rise in economic activity and population has brought about an increase in the need for water, which is almost totally met from groundwater. To this fact must be added the exportation of groundwater from this and the neighboring valley (Valle de Ixtlahuca-Atlacomulco) to Mexico City and its surrounding metropolitan area to meet demand there. This represents an average flow of $5.3 \mathrm{~m}^{3} / \mathrm{s}$ (Birkle et al. 1998), although values of $14.5 \mathrm{~m}^{3} / \mathrm{s}$ have been reached.

Intensive exploitation of the Valle de Toluca and Ixtlahuca-Atlacomulco aquifers has occurred in two phases. The first, between 1941 and 1965, affected only the Valle de Toluca. Fifty wells were drilled, headworks were constructed in several springs, and $6.5 \mathrm{~km}$ of water pipe were laid, through which a maximum flow of $4.5 \mathrm{~m}^{3} / \mathrm{s}$ is conducted to Mexico City. However, a crisis of availability of water led a presidential edict to be signed on
August 10, 1965, establishing a ban on this aquifer in order to protect it. In the same year the demand for water in Mexico City could not be met and so another agreement was signed between the Federal District Department, the Hydraulic Resources Secretary and the Government of the State of Mexico to increase extractions in the area of the Lerma River, which cancelled the previous presidential edict (Boehm and Sandoval 1999). This agreement led to the second phase of exploitation (19661976) affecting both valleys. During that period 230 wells were drilled and $170 \mathrm{~km}$ of water pipes were laid, contributing an additional volume of $10 \mathrm{~m}^{3} / \mathrm{s}$, which is presently conducted to Mexico City and its suburbs.

These abstractions, together with those needed to meet the demands of the population within the valley, its industry and agriculture, have caused a dramatic lowering of the water table, land subsidence, drying up of springs and lagoons, as well as a decrease in river flows. To these negative results, resulting from the overexploitation of the aquifer determined in previous studies (Esteller and DíazDelgado 2002), others should be added, such as degradation of groundwater quality, due to an increase in either its salinity or in the concentration of certain chemical compounds (Custodio 1992; Baretta et al. 1992; Martinelli et al. 1998). 
Monitoring of exploitation is performed by the Water National Committee by means of a piezometric network, which at present consists of 50 monitoring wells, and from which only annual data are available. The purpose of this network is to monitor the evolution of the water table and the rate of pumping from the aquifer.

The quality of the groundwater is not monitored using a specific network, and the urban supply agencies are the same as those in charge of monitoring the evolution of required conditions to comply with the Mexican law on potable water. Furthermore, there are few studies of the hydrogeochemistry of this aquifer. The most important one was carried out by DGCOP (1984), which made a general characterization of the aquifer waters.

Because of the lack of a network to monitor groundwater quality, it is not known whether the anthropic actions affecting this aquifer over the years have produced variations in water quality. The main objective of the present study is to evaluate the changes in the physicochemical characteristics of the groundwater that have arisen as a consequence of the intensive exploitation the aquifer. To achieve this aim, the starting point is the information available from chemical analyses and from sampling programs of the present study.

\section{Physical setting}

\section{Location}

The study area is located in the heart of the Mexican Republic, at the center of the State of Mexico, within the upper reach of the Lerma River (upper watershed of the Lerma River). This watershed is one of the highest valleys of the Highlands of Mexico, with a mean elevation of 2,570 m.a.s.l. and an extension of about $900 \mathrm{~km}^{2}$ (Fig. 1). The upper reach of the Lerma River comprises the flow from the northeast face of the Nevado de Toluca volcano $(4,690 \mathrm{~m}$ a.s.l.) and the flow from the southwestern slopes of the Sierra de las Cruces mountain. The upper reach ends where the tectonic creeping of the AtlacomulcoIxtlahuca Valley (formed by the Perales block and fault systems) descends (Deman et al. 1976).

There is a wetland area, the Almoloya Lagoons, which is considered to be the source of the Lerma River. The size of these lagoons has been shrinking over the years, due to the aquifer exploitation and to the reduced inflow to the springs feeding them. As a consequence, the river has lost flow and declined in quality because freshwaters have been supplanted by the wastewaters from urban and industrial areas.

\section{Climate}

Total annual rainfall varies from $1,300 \mathrm{~mm}$ in the highest areas to $700 \mathrm{~mm}$ in the lowland area. The most intense rainfall is in the highest sectors, where 80 to $120 \mathrm{~mm}$ can fall in a single day. Rainfall over the rest of the area is between 60 to $80 \mathrm{~mm} /$ day. Approximately $90 \%$ of the rainfall occurs between May and October. In the Valle de Toluca the annual average temperature ranges from 12 to
$16{ }^{\circ} \mathrm{C}$, with May being the warmest month $\left(14-15{ }^{\circ} \mathrm{C}\right)$ and January the coldest $\left(11-12{ }^{\circ} \mathrm{C}\right)$, while in the mountainous areas the annual average is $12-14^{\circ} \mathrm{C}$, with a minimum in the Nevado de Toluca (annual means from -2 to $5{ }^{\circ} \mathrm{C}$ ) (SDA 1992). Estimates of real evapotranspiration (Turc's Method) range from 754 to $453 \mathrm{~mm}$, with an average of about $579 \mathrm{~mm}$, with maximum values recorded in April and May and minimum ones in January and December.

\section{Land use}

Land use is mainly seasonal agriculture although there are also irrigated croplands in the northwest of the area, where maize is the prevailing crop, with smaller areas of dry beans, potatoes, oats and vegetables. The extent of this agricultural land has been diminishing over the years due to the expansion of urban areas: at present $55.6 \%$ of the surface area is agricultural and $11.5 \%$ is urban. The area of forest has also been reduced and now comprises only $23 \%$ of the surface area, with forests located on the upper hill slopes. Pasture land occupies $7.8 \%$ of the total area. Water bodies, hydrophilic vegetation and forests occupy the remainder of the land.

\section{Hydrogeological setting}

The Valle de Toluca is located in the physiographic province called "Eje Neovolcánico Transmexicano" (Trans-Mexican Neovolcanic Axis) (Deman et al. 1976). It is a region that consists of a volcanic strip of calcoalkaline type rocks of Cenozoic age. The lithological sequence consists of andesites and rhyolites from the Oligocene, andesites from the Miocene and basalts and andesites from the Quaternary, as well as pyroclastic materials and breccias outcropping on the hills flanking the valleys. Lacustrian and alluvial sediments intercalated with clastic materials of volcanic origin (pyroclasts, tuffs and breccias) can be observed in the valleys. The thickness of this formation ranges from only a few meters at the valley sides to over $500 \mathrm{~m}$ in the deepest parts. A late Pliocene-Quaternary age is assigned to these deposits (Honorio and Hernández 1982; Herrera and Sánchez 1994).

The Valle de Toluca aquifer (Fig. 2) is composed of detrital materials of alluvial and lacustrine origin. There is a wide variation in particle size, with a predominance of gravel, sand and conglomerate within a clay-silt matrix. Intercalations of beds of pyroclasts, breccias and tuffs can also be distinguished, which are much more frequent with depth. On the basis of these characteristics, it is clear that this system is composed of several superimposed aquifer levels constituting a multilayer aquifer, though the existence of hydraulic continuity means that it can be considered as a single flow system. Nevertheless, locally there are significant differences of hydraulic heads (UNITECNIA 1996). These detrital materials overlie the bedrock comprised of consolidated volcanic material of variable lithology. 
Fig. 2 Geological map of the upper course of the Lerma River

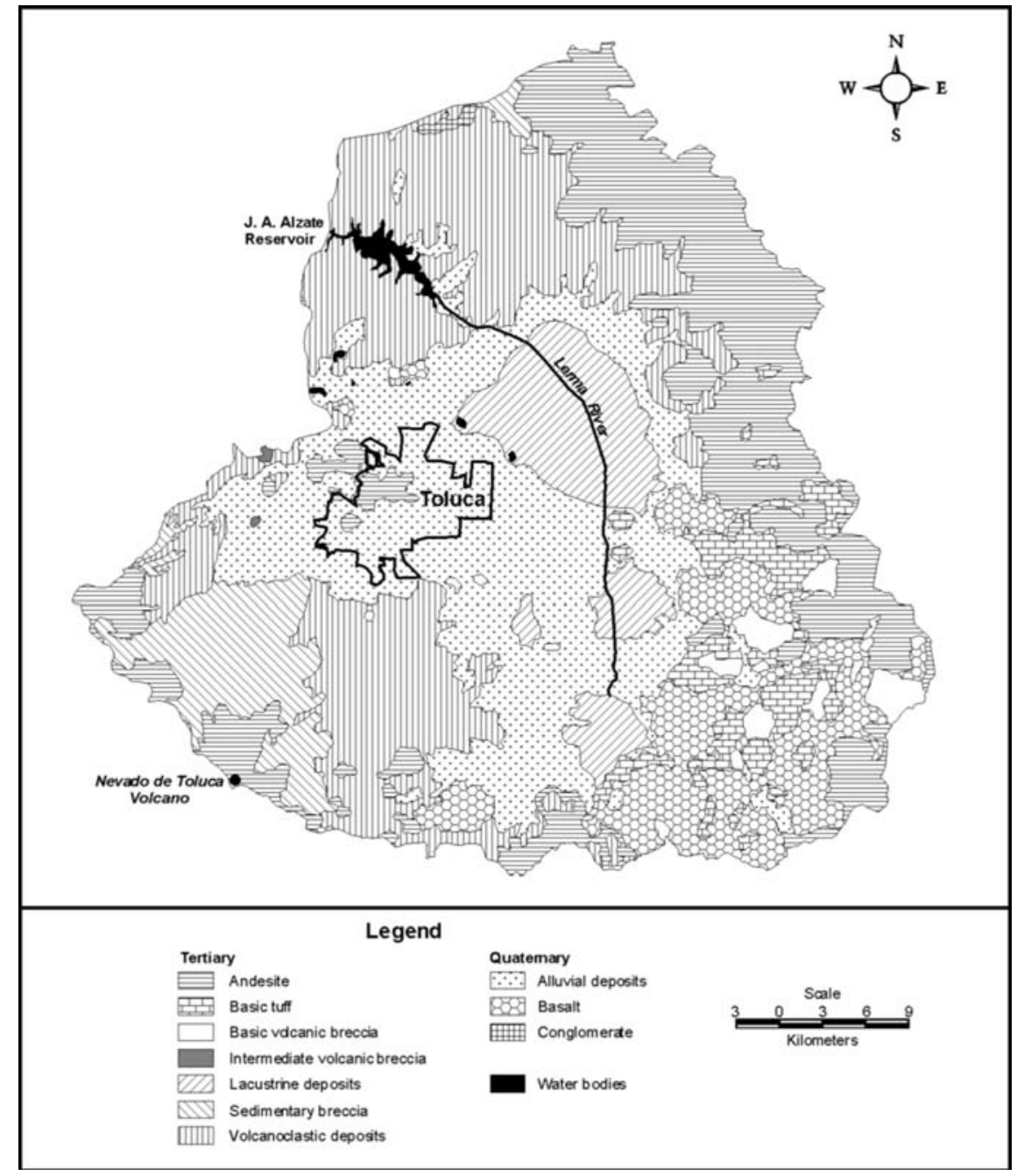

The edges of the aquifer are defined by the volcanic materials-mainly basalts, andesites and pyroclastic deposits-that crop out in the Sierra de las Cruces mountains, the Nevado de Toluca volcano and the Sierra de Nahuatlaca-Matlazinca, which, in turn constitute important fractured aquifers.

The hydraulic parameters of the aquifer vary widely due to the lithological and geometric variability of the deposits. Hydraulic conductivity values range from 4 to $80 \mathrm{~m} /$ day. Different areas can be distinguished according to their conductivity: the area corresponding to the Alzate Reservoir with values ranging from 4 to $12 \mathrm{~m} / \mathrm{day}$, the Almoloya area with values of between 40 and $81 \mathrm{~m} /$ day and the central part with a conductivity varying around $4 \mathrm{~m} /$ day (Ariel 1996). The storage coefficient varies between 0.3 and $0.9 \%$ (CCRECRL 1993).

The hydraulic balance of the aquifer shows that the total input can be quantified as some $380 \mathrm{hm}^{3} /$ year, of which $101 \mathrm{hm}^{3} /$ year comes from the lateral flow of the Nevado de Toluca, $198 \mathrm{hm}^{3} /$ year from the lateral flow of Sierra de las Cruces and $81 \mathrm{hm}^{3} /$ year from direct rainfall infiltration. Output is estimated in $385 \mathrm{hm}^{3} /$ year, due to underground discharges to the Valle de Ixtlahuaca-Atla- comulco with a value of $2 \mathrm{hm}^{3} /$ year and to pumping, quantified as $383 \mathrm{hm}^{3} /$ year. The global balance of the aquifer indicates an imbalance between input and output, as output is higher than input by $5 \mathrm{hm}^{3} /$ year (CCRECRL 1993).

Of the total volume extracted, $163 \mathrm{hm}^{3} /$ year are used in the Valle de Toluca itself (79\% for urban use, $12.9 \%$ for the industry and $8.1 \%$ for agricultural activities) and $220 \mathrm{hm}^{3} /$ year $\left(6.9 \mathrm{~m}^{3} / \mathrm{s}\right)$ are piped to Mexico City to meet its demands for potable water $\left(167 \mathrm{hm}^{3} /\right.$ year $)$ and irrigation $\left(53 \mathrm{hm}^{3} /\right.$ year $)$.

This intensive exploitation has caused a drawdown of the water table over practically the whole of the aquifer (Fig. 3). The largest depressions have occurred in the surroundings of Toluca City where levels declined more than 15 m between 1984 and 1997.

On the potentiometric head maps of Fig. 4, for the years 1984 and 1997, it can be observed that there were no significant changes in the direction of groundwater flow, although there were variations in the water-table configuration. The main recharge to the aquifer comes from the Sierra de las Cruces mountain and Nevado de Toluca volcano; providing a flow towards the center of 
Fig. 3 Map of drawdown isopleths in meters between 1984 and 1997 (isopleth contour interval $2 \mathrm{~m}$ )

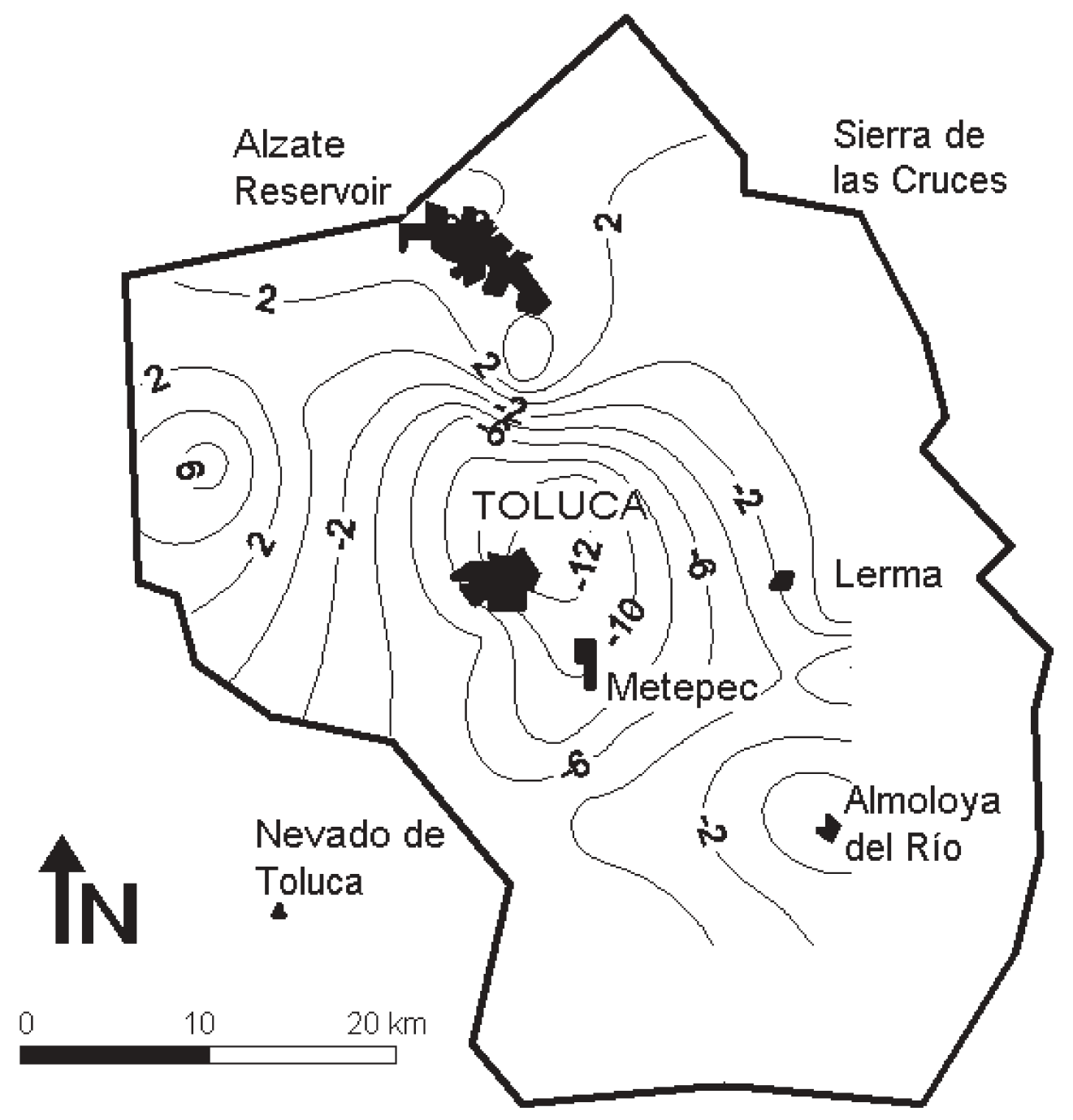

the valley, which splits in three directions, towards the east and southeast until it reaches the bottom of the Sierra de las Cruces mountains, and towards the north to the Atlacomulco-Ixtlahuaca valley.

The conceptual hydrogeological model of this valley is based on flow from the mountain flanks towards the center of the valley, following a northwest direction along the riverbed of the Lerma River. Recharge of the aquifer occurs mainly in the higher areas through the outcropping basaltic and andesitic rocks, which, due to their fracture properties, have excellent hydraulic characteristics. Discharge of the aquifer occurs almost exclusively through pumping.

In hydrogeological studies based on the use of isotopes (Segovia et al. 1999) the flow system of the aquiferdefined by a local and a regional flow-could be determined in more detail. The local flow is characterized by a short period of water-rock contact, a shallow circulation depth and recharge through alluvia, basalt and andesite formations. The regional flow, on the other hand, is characterized by a longer contact time, a deeper circulation and recharge through the Tertiary (Oligocene) rhy- olites and andesites (Fig. 5). The physico-chemical characteristics of the regional flow indicate a higher salinity, high $\mathrm{Na}^{+}$and $\mathrm{K}^{+}$content and a relatively high temperature (mean temperature of $23{ }^{\circ} \mathrm{C}$ ).

\section{Methods}

The study of the hydrochemical evolution of the Valle de Toluca aquifer has been based on a comparative analysis of data obtained in two surveys, in 1984 (DGCOP 1984) and in 1998, respectively, together with a compilation and treatment of historical chemical analyses carried out by the Comisión Estatal de Agua y Saneamiento (CEAS) (Water and Drainage State Committee) of the State of Mexico.

The 1984 sampling survey consists of 138 sites. In the majority of the samples the following chemical and physical parameters were analyzed: $\mathrm{pH}$, electric conductivity, bicarbonate, sulfate, chloride, nitrate, calcium, magnesium, potassium, iron, manganese, hardness and total dissolved solids. The 1998 sampling program con- 

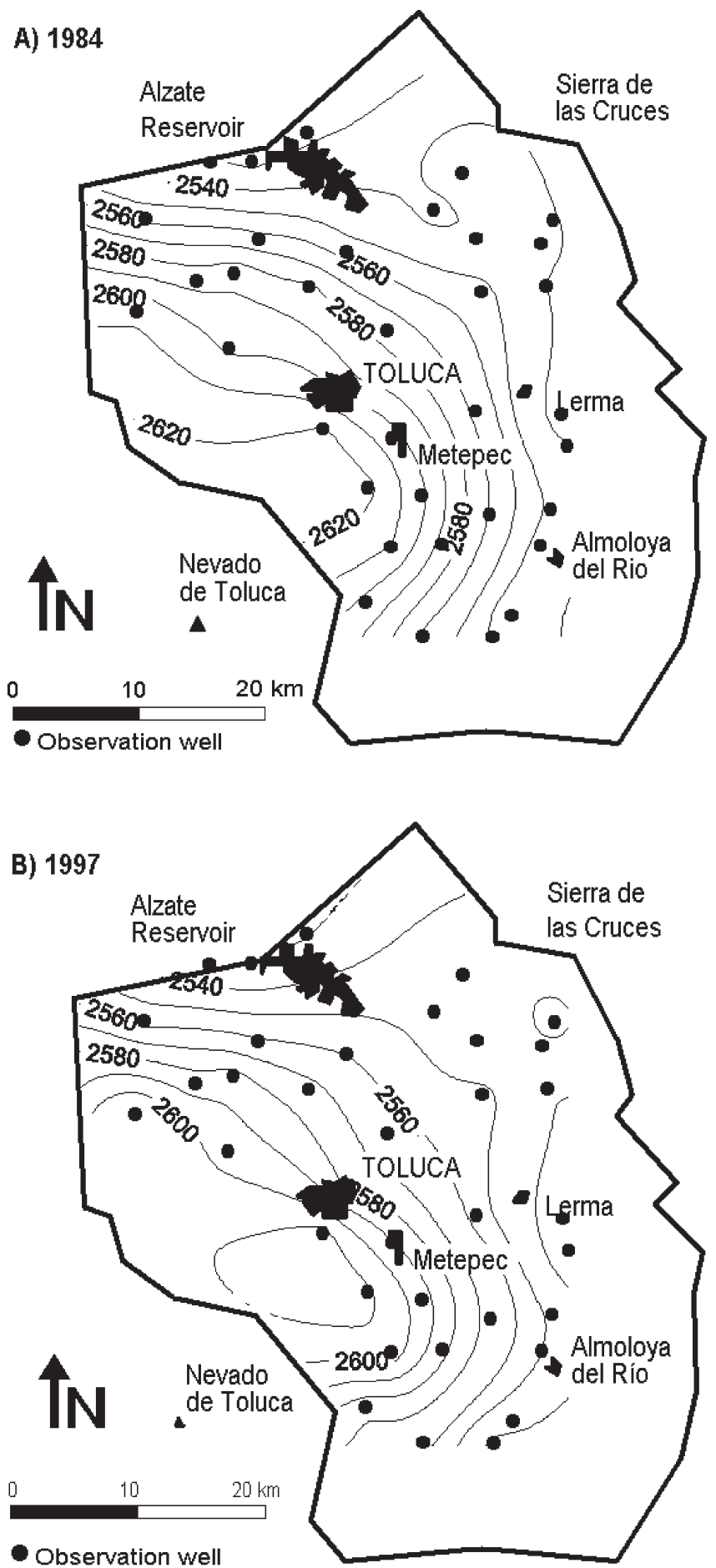

Fig. 4 Distribution of potentiometric head in the study area. A 1984; B 1997

sists of 38 sites. Temperature, $\mathrm{pH}$ and electric conductivity were determined in the field, while the rest of the parameters were measured in the laboratory. The analysis protocol followed the regulations enforced in Mexico, which are based on methods proposed by the APHA, AWWA and WEF (1995). Bicarbonate and chloride ions were determined by titration, sulfates by turbidimetry, nitrates by spectrophotometry UV-Vis and cations by atomic adsorption. Temperature, $\mathrm{pH}$ and electric conductivity were determined using portable equipment (Checkmate Hand-Held Analysis System).

CEAS data derive from samples taken in 1993 and 1997. Samples were analyzed at the Water Quality Control Laboratory of the Mexican Government. Aside from the major elements, minor elements such as $\mathrm{F}, \mathrm{Fe}$ and $\mathrm{Mn}$, and trace elements such as $\mathrm{Al}, \mathrm{As}, \mathrm{Ba}, \mathrm{Cd}, \mathrm{Cu}$, total $\mathrm{Cr}$, $\mathrm{Hg}, \mathrm{Pb}$, and $\mathrm{Zn}$, were also analyzed, as well as fecal and total coliforms.

Isopleth maps of the most important parameters have been drawn using the SURFER V.6 program (Golden Software Inc. 1997). Likewise, a Piper diagram has been used to define the different hydrochemical groups. For the statistical study, multivariate analysis was used (Davis 1986; Brown 1998), which classifies the variables (physico-chemical characteristics of the different samples) and observations (sampling sites), as well as establishing relationships among them. This type of analysis has been used in numerous hydrogeochemical studies, allowing differentiation of waters from different origins and the identification of processes (natural and anthropic) that modify the physico-chemical characteristics of the waters (Melloul and Collin 1992; Ritzi et al. 1993; Morell et al. 1996).

For the characterization of groups, cluster analysis was applied. This aims to quantify those statistical parameters or equations that allow the differentiation of groups within the data set. A study of the interdependencies was done using principal components analysis (PCA). This seeks to reduce the number of variables (which is usually high in hydrochemical studies), and replace it by a smaller number of new, uncorrelated variables. These new variables are the principal components that arise from the linear combination of the original variables. In this way, relationships among variables (R-mode) and/or samples (Q-mode) are established and the contribution of each one or of each combination in the structure of the hydrochemical data is defined.

\section{Results and discussion}

\section{Chemical types of groundwater}

Figure 6 shows Piper diagrams corresponding to the 1984 and 1998 campaigns. Broadly speaking, it can be observed that the groundwater is basically a bicarbonate water, with $\mathrm{Mg}^{2+}$ and $\mathrm{Na}^{+}$being the prevailing cations. Such mineralization coincides with the one that in theory groundwater from a volcanic environment must possess; feldspars contribute sodium, calcium and potassium, and the pyroxenes and biotites contribute calcium, magnesium, iron, and manganese. The abundance of sulfates and chlorides is low, due to the fact that volcanic rocks contain such ions in small amounts (Custodio and Llamas 1983; Appelo and Postman 1993). However, it can be seen that some well samples show sulfate contents exceeding $120 \mathrm{mgL}^{-1}$. A notable feature is that these sam- 


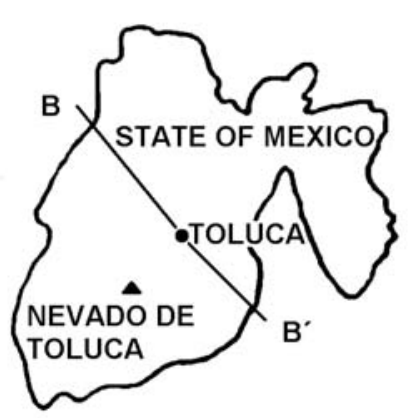

LEGEND
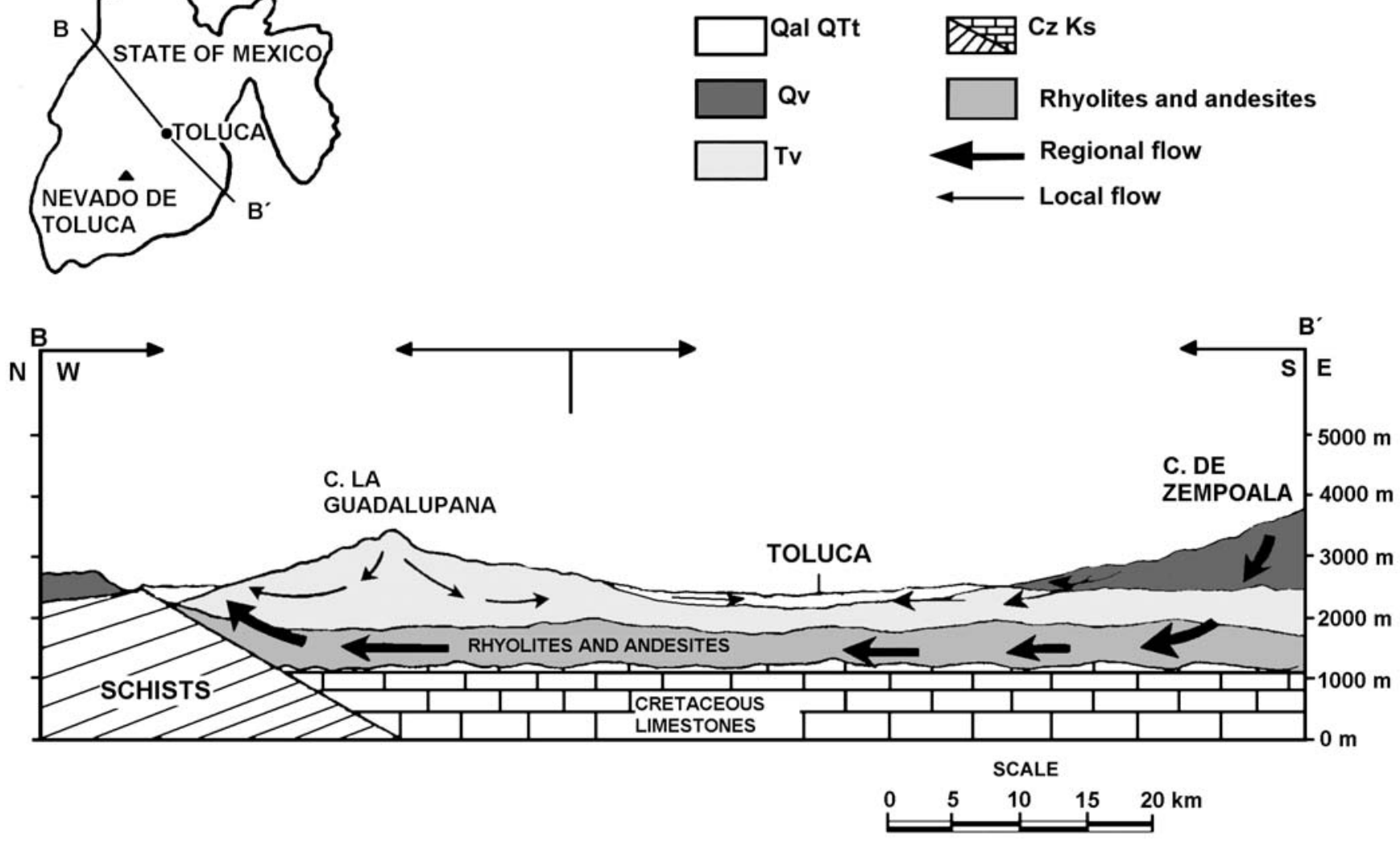

Fig. 5 Regional geological profile indicating the regional and local groundwater flows (after Segovia et al. 1999). (Qal alluvium material, QTt pyroclastic breccia and basaltic tuffs, Qv basaltic material, Tv andesitic and basaltic units, Cz schist, Ks limestones)

pling sites are all shallow wells taking water from the most surficial level and this suggests that they may indicate contamination from ammonium sulfate fertilizers, which are frequently applied in the region.

A more detailed study of the water type verifies that in the 1984 sampling program magnesium-bicarbonate waters prevail (74\% of the samples are the $\mathrm{Mg}$ type and $26 \%$ the Na type), while in the 1998 campaign sodium ones prevail $(62 \%$ of the samples are the Na type and $38 \%$ the $\mathrm{Mg}$ type). It has been proved that in this type of geological environment waters of the sodic type are related to acidic volcanic materials such as rhyolites and trachytes, while magnesium type waters would be linked to basic volcanic materials like basalts and andesites (Appelo and Postman 1993).

Taking into account the geology of this aquifer and its flow system comprising both local and regional flow (Fig. 5), this change in the predominant cation types may be related to variations in the type of prevailing flow. Thus, in 1984 a local flow linked to basalts, andesites and detrital material of sedimentary and volcanic type would have prevailed, while in 1998 the regional flow related to the Oligocene rhyolites and andesites would predominate. Such a change of flow would be promoted by a fall in the piezometric level over the whole aquifer, resulting in water abstractions from increasingly deeper levels.
As mentioned above, the groundwater flow model proposed for this aquifer includes water coming from the regional flow zone, which would typically have high $\mathrm{Na}^{+}+\mathrm{K}^{+}$contents, and higher temperature and conductivity compared to water coming from the local flow zone. In order to verify this idea, the relationship between temperature and $\mathrm{Na}^{+}+\mathrm{K}^{+}$, were defined, as well as between temperature and electric conductivity for the 1998 sampling program (there are no data on temperature for the 1984 sampling program) (Fig. 7). This exercise indeed verified that the higher the temperature, the higher the salinity and $\mathrm{Na}^{+}+\mathrm{K}^{+}$in the water. There are some sites, however, which were not in accord with this pattern, with high sulfate content $\left(252 \mathrm{mgL}^{-1}\right)$ distinguishing them from the proposed model. In general, these sampling sites were shallow wells extracting water from surficial aquifer levels. By eliminating these sites from the calculation of the correlation coefficient, closer correlations are obtained; in the case of the correlation between temperature and electric conductivity it increases from 0.22 to 0.64 and in the case of $\mathrm{Na}^{+}+\mathrm{K}^{+}$, from 0.50 to 0.75 .

\section{Spatial distribution of electrical conductivity and $\mathrm{NO}_{3}$}

Figures 8 and 9 show the isopleth maps corresponding to electrical conductivity and nitrates for 1984 and 1998, 

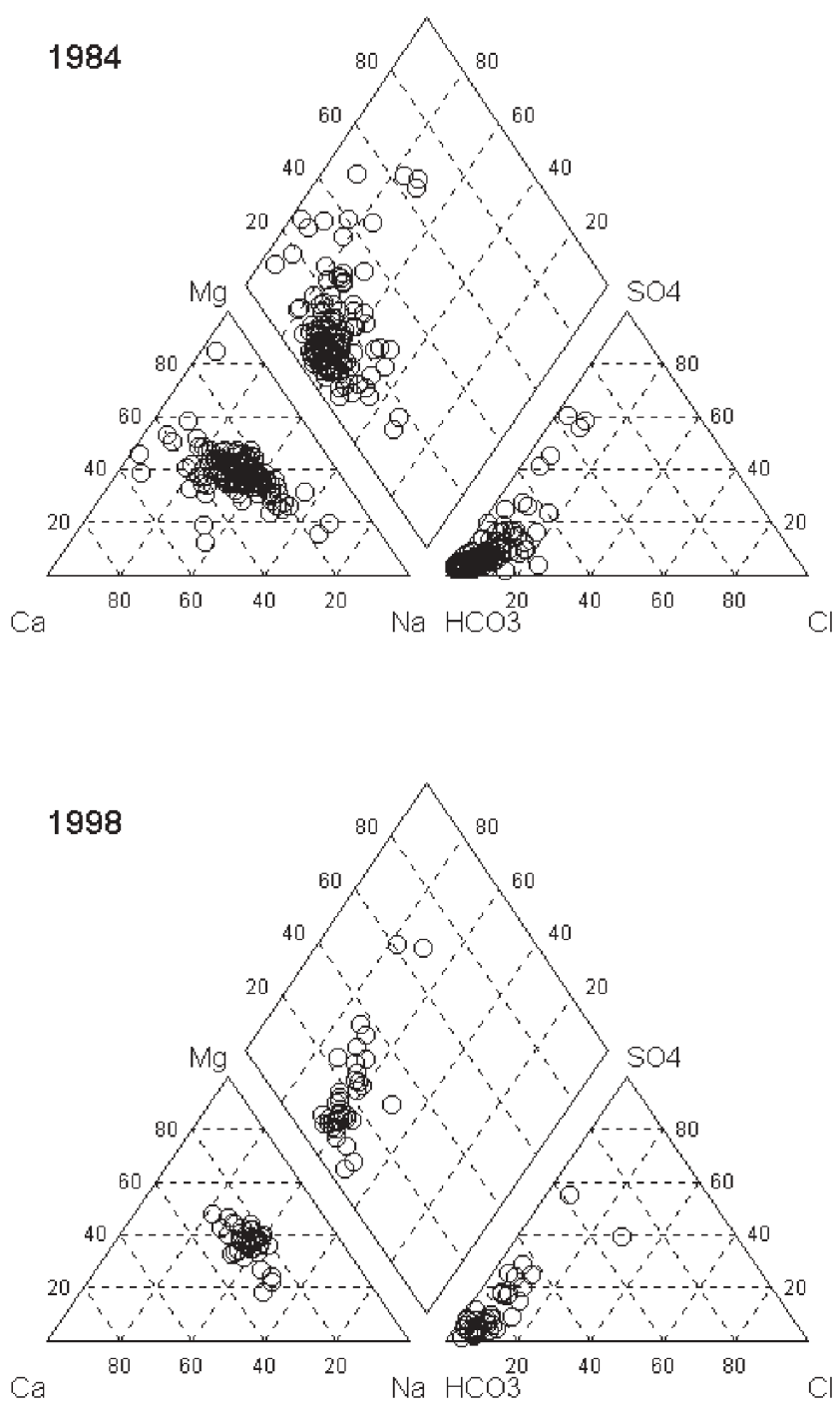

Fig. 6 Piper diagram of hydrochemical data in the Valle de Toluca aquifer (1984 and 1998)

respectively. Electrical conductivity has been chosen as an indicator of the degree of mineralization of groundwater, and nitrate as an indicator of pollution.

In the case of electric conductivity, a comparison of the two maps (Fig. 8 A, B) indicates an increase in those sectors where exploitation has increased and where the water table is lowest. Thus, for example, in the Toluca City sector conductivity increased from 200 microS cm $\mathrm{cm}^{-1}$ to 400 microS $\mathrm{cm}^{-1}$ and in the sector bordering Sierra de las Cruces, from 200 to 800 microS cm$~^{-1}$. This fact correlates with changes in the physico-chemical characteristics of groundwater and so with changes in the residence times and/or degree of mixing with waters from different sources. So it can be deduced that, initially, the groundwater abstractions had a higher percentage of the local flow component, while water was subsequently abstracted from a deeper, more mineralized level related to the regional flow zone. This change of flow type was a result of
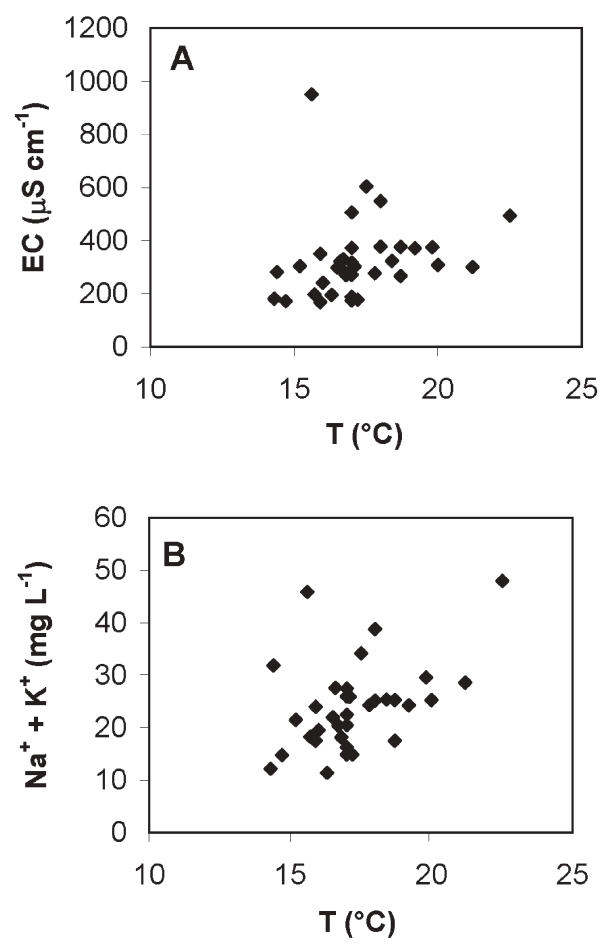

Fig. 7 Relationship between temperature and A electrical conductivity (EC) and $\mathbf{B ~} \mathrm{Na}^{+}+\mathrm{K}^{+}$

the intensive exploitation to which the aquifer was subjected.

Nitrate concentration has also undergone variations in both space and time. In the 1984 map (Fig. 9A), it can be observed that most of the aquifer contained concentrations below $2 \mathrm{mgL}^{-1}$, while in 1998 (Fig. 9B) this ion concentration had increased, with several sectors containing concentrations in excess of $10 \mathrm{mgL}^{-1}$. The highest values occur in the center of the aquifer, while the lowest ones are located in the recharge areas (Sierra de las Cruces and Nevado de Toluca). The origin of this nitrate seems to be related not only to the use of nitrogenous fertilizers but also to wastewaters from urban areas.

At some sampling sites nitrate concentrations exceeded the limit admissible by the potable water regulations (DOF 1994), which is $50 \mathrm{mg} \mathrm{L}^{-1}$.

\section{Multivariate analysis}

\section{Cluster analysis}

In the dendrogram for the 1984 sampling program (Fig. 10A) two main groups can be distinguished, one of them formed by electric conductivity, $\mathrm{Ca}^{2+}, \mathrm{SO}_{4}{ }^{2-}$ and $\mathrm{Cl}^{-}$ and the other by $\mathrm{Mg}^{2+}$ and $\mathrm{HCO}_{3}{ }^{-}(\mathrm{r}=0.71)$, while the rest of the variables show little correlation with each other. The two groups indicate which hydrochemical parameters are basically linked to the flow from rainfall infiltration $\left(\mathrm{Cl}^{-}, \mathrm{SO}_{4}{ }^{2-}\right)$, and which, to lateral flow from the fractured volcanic aquifers bounding the valley $\left(\mathrm{Mg}^{2+}, \mathrm{HCO}_{3}^{-}\right)$. In the 1998 sampling program (Fig. 9B) two groups can also be differentiated, one formed by electric conductivity, 
A) 1984

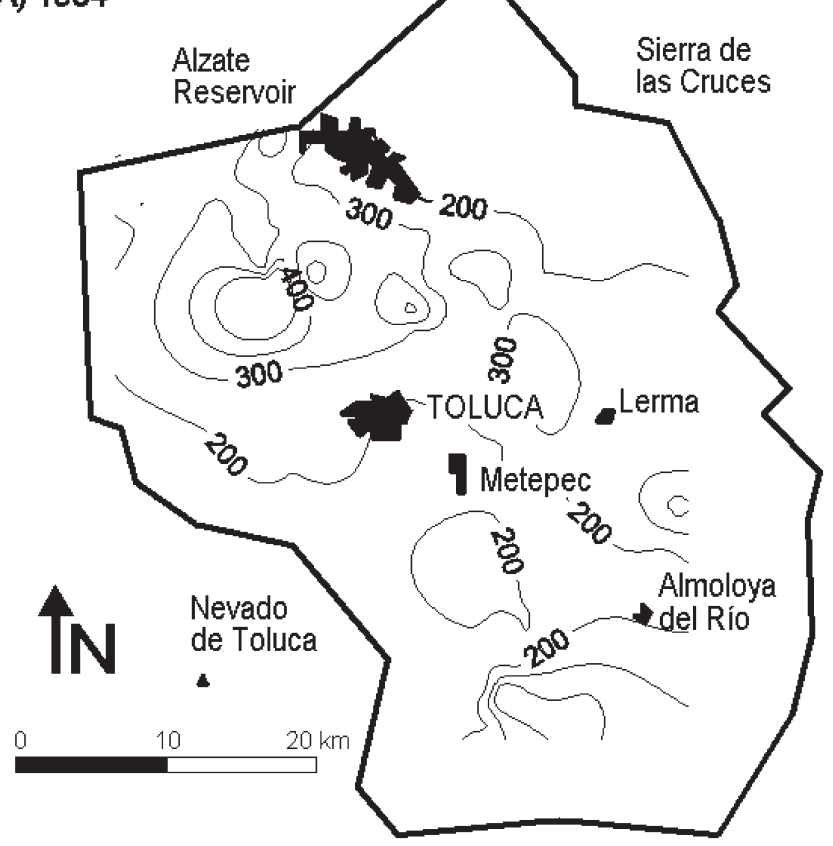

B) 1998

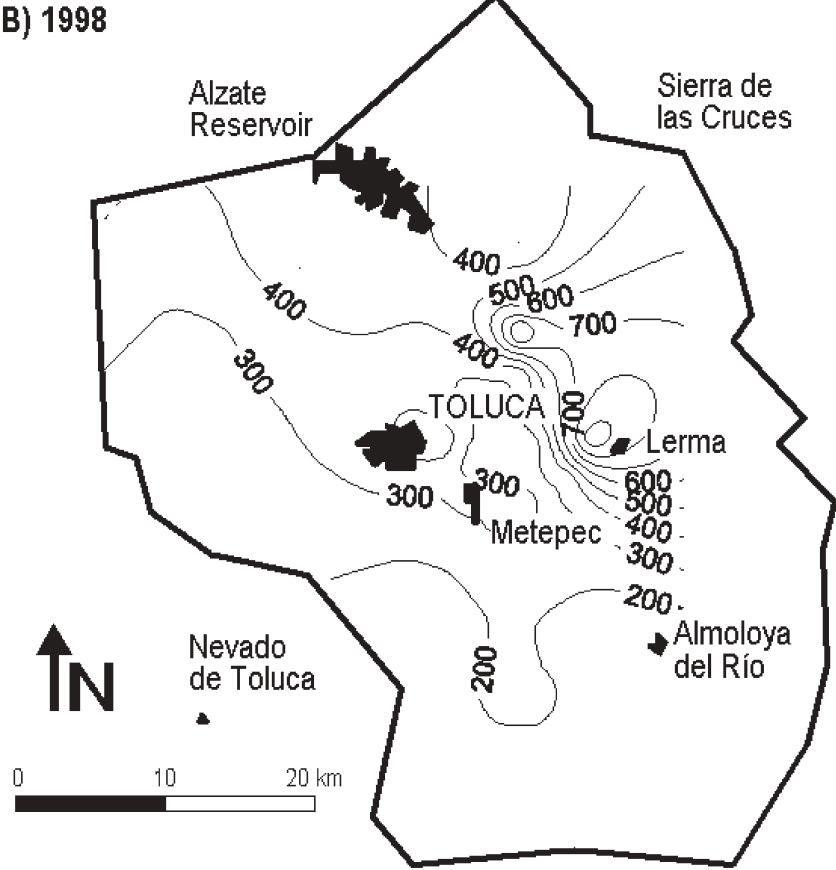

Fig. 8 Distribution of isopleth lines of electrical conductivity for the Valle de Toluca aquifer. A 1984, B 1998 (in microS cm $\mathrm{cm}^{-1}$, isopleth interval 100 microS $\mathrm{cm}^{-1}$ )

$\mathrm{Mg}^{2+}, \mathrm{Ca}^{2+}$ and $\mathrm{SO}_{4}{ }^{2-}$ and the other by $\mathrm{HCO}_{3}{ }^{-}$and $\mathrm{Na}^{+}$ $(\mathrm{r}=0.85)$. The latter could represent the contribution of water from regional flow zone in the rhyolites, while the former may reflect the chemistry of the local flow zone that results from the mixture of rainwater infiltration with the predominant lateral flow from the adjacent volcanic

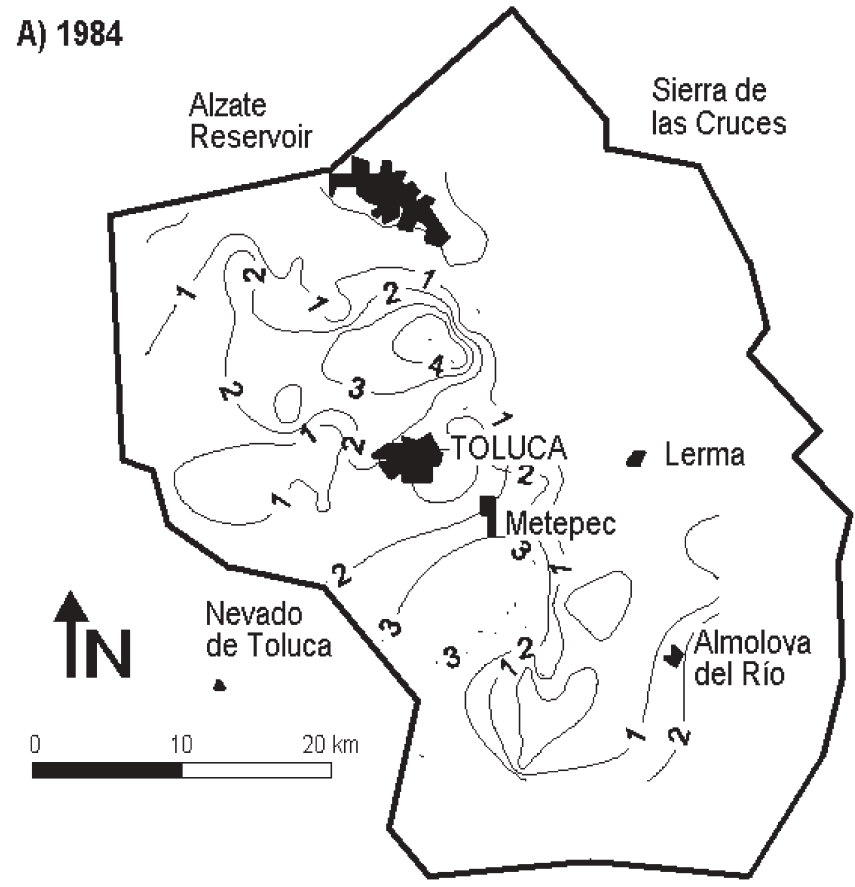

B) 1998

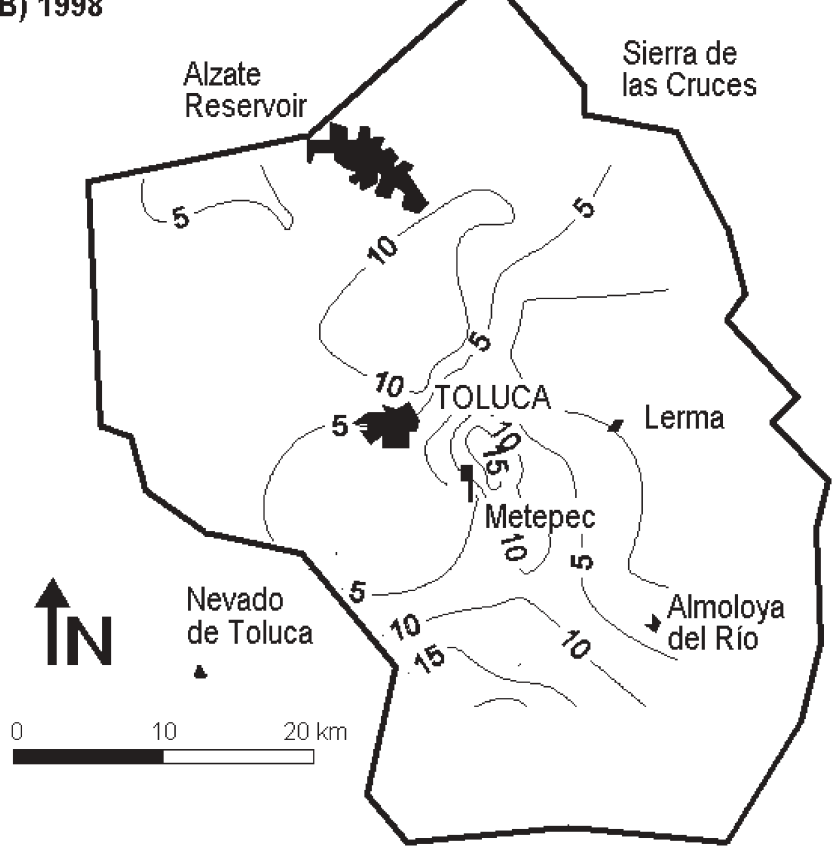

Fig. 9 Distribution of isopleth lines of nitrate concentration for the Valle de Toluca aquifer. A 1984, B 1998 (in $\mathrm{mg} \mathrm{L}^{-1}$, respective isopleth intervals, 1 and $5 \mathrm{mg} \mathrm{L}^{-1}$ )

aquifers. It can be concluded that the grouping of variables is based on the origin of the water recharging the aquifer.

With respect to nitrates, the lack of relationship with the rest of the physico-chemical parameters suggests that its origin is related to human activities. 
Squared Euclidean distance
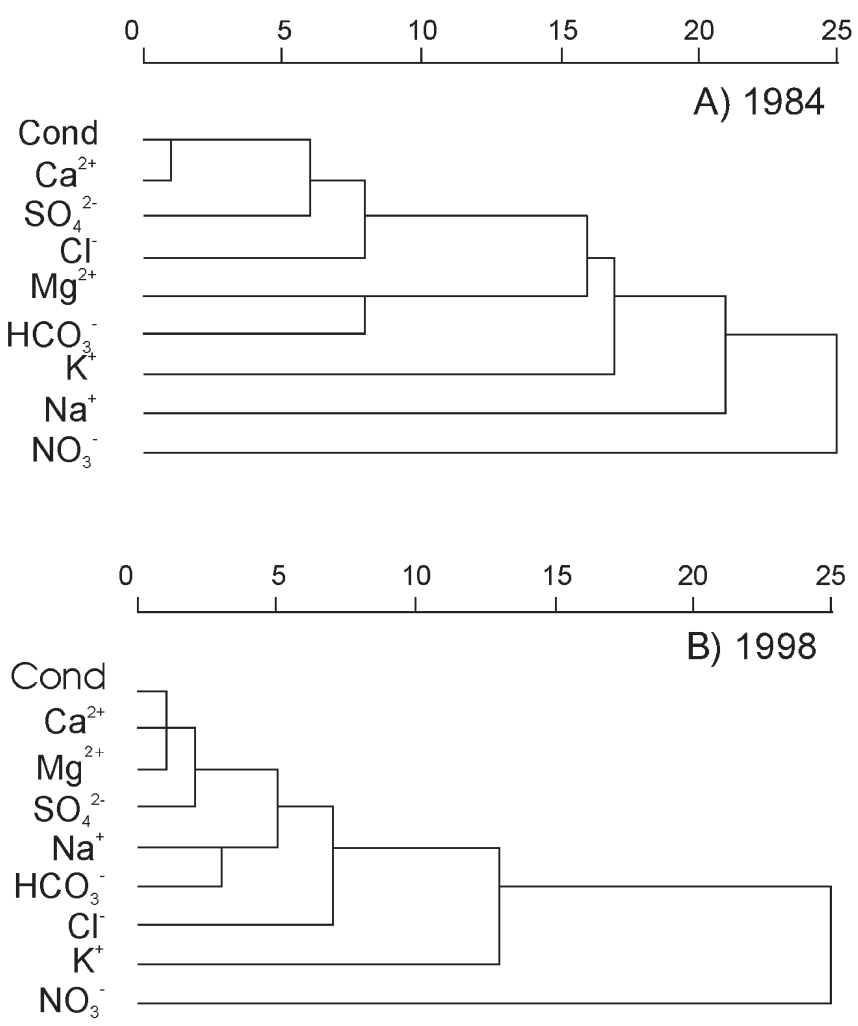

Fig. 10 Dendrogram of cluster analysis between variables A 1984, B 1998

\section{Principal components analysis}

This analysis was applied to data from both sampling programs using the variables electric conductivity, bicarbonates, sulfates, chlorides, nitrates, sodium, calcium, magnesium, and potassium (R-mode method, interrelationships between variables); and to the samples (Q-mode method, interrelationships between samples).

R-mode: From the similarity matrix, the principal components and the distribution of variables were determined. Table 1 shows the principal components, weights of components, and associated variance explained in the physico-chemical data and communalities. Verification that application of this method is appropriate is supplied because the variables have high communalities and every variable is included in the model.

For the 1984 sampling program, component I explains $55.1 \%$ of the total variance, while component II explains $17.5 \%$. The spatial distribution of variables based on the first two components (Fig. 11A) shows that component I discriminates in terms of salinity (major anions and cations), while the second component differentiates ions of anthropogenic origin such as $\mathrm{NO}_{3}{ }^{-}$. It could be concluded that component I represents the natural processes by which water acquires its chemical characteristics (in this case the mixture of lateral flow waters from the volcanic
Table 1 Principal components matrix and communalities for each parameter analyzed for water in the Valle de Toluca aquifer (1984 and 1998 sampling programs)

\begin{tabular}{|c|c|c|c|c|}
\hline 1984 & $\begin{array}{l}\text { Compo- } \\
\text { nent I }\end{array}$ & $\begin{array}{l}\text { Compo- } \\
\text { nent II }\end{array}$ & $\begin{array}{l}\text { Compo- } \\
\text { nent III }\end{array}$ & $\begin{array}{l}\text { Commu- } \\
\text { nalities }\end{array}$ \\
\hline EC & 0.9620 & -0.0248 & -0.0565 & 0.9293 \\
\hline $\mathrm{Ca}^{2+}$ & 0.9092 & 0.2024 & -0.0358 & 0.8689 \\
\hline $\mathrm{Mg}^{2+}$ & 0.7389 & -0.0276 & 0.1751 & 0.5774 \\
\hline $\mathrm{Na}^{+}$ & 0.5235 & -0.6723 & -0.3482 & 0.8473 \\
\hline $\mathrm{K}^{+}$ & 0.6661 & -0.1959 & 0.5274 & 0.7602 \\
\hline $\mathrm{HCO}_{3}^{-}$ & 0.7441 & -0.5514 & 0.2650 & 0.9280 \\
\hline $\mathrm{SO}_{4}^{2-}$ & 0.7965 & 0.1318 & -0.3952 & 0.8080 \\
\hline $\mathrm{Cl}^{-}$ & 0.7425 & 0.4239 & -0.2942 & 0.8176 \\
\hline $\mathrm{NO}_{3}^{-}$ & 0.4517 & 0.7378 & 0.2749 & 0.8240 \\
\hline $\begin{array}{l}\text { Variance } \\
\text { explained (\%) }\end{array}$ & 55.1 & 17.5 & 9.1 & \\
\hline $\begin{array}{l}\text { Cumulative (\%) } \\
1998\end{array}$ & 55.1 & 72.6 & 81.7 & \\
\hline $\mathrm{EC}$ & 0.9863 & -0.0212 & -0.0725 & 0.9785 \\
\hline $\mathrm{Ca}^{2+}$ & 0.9710 & 0.0057 & -0.0902 & 0.9510 \\
\hline $\mathrm{Mg}^{2+}$ & 0.9486 & -0.1892 & -0.1162 & 0.9491 \\
\hline $\mathrm{Na}^{+}$ & 0.9096 & 0.1093 & 0.1372 & 0.8581 \\
\hline $\mathrm{K}^{+}$ & 0.5329 & 0.7788 & 0.1751 & 0.9212 \\
\hline $\mathrm{HCO}_{3}^{-}$ & 0.8676 & 0.2865 & 0.2855 & 0.9163 \\
\hline $\mathrm{SO}_{4}^{2-}$ & 0.8695 & -0.1631 & -0.1888 & 0.8183 \\
\hline $\mathrm{Cl}^{-}$ & 0.7486 & -0.4307 & -0.2820 & 0.8254 \\
\hline $\mathrm{NO}_{3}^{-}$ & -0.2133 & 0.4872 & -0.8382 & 0.9854 \\
\hline $\begin{array}{l}\text { Variance } \\
\text { explained (\%) }\end{array}$ & 67.1 & 13.2 & 10.8 & \\
\hline Cumulative (\%) & 67.1 & 80.3 & 91.1 & \\
\hline
\end{tabular}
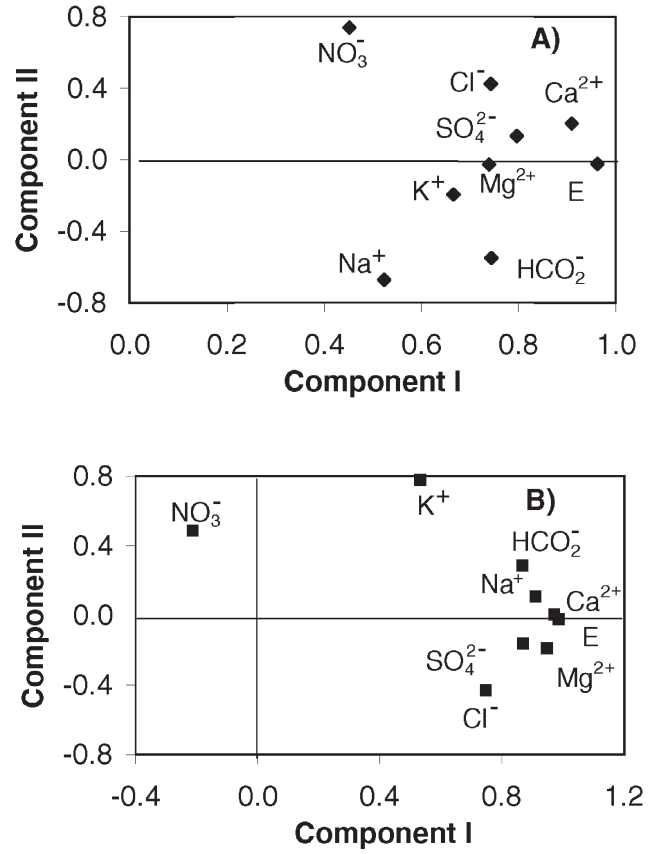

Fig. 11 Behaviour of the variables in the principal components analysis with respect to the first two components; A 1984, B 1998

aquifers and infiltration waters from the local flow zone), whereas component II represents the prevalence of pollution.

In the case of the 1998 sampling program, the contribution of components I and II to the total variance is 

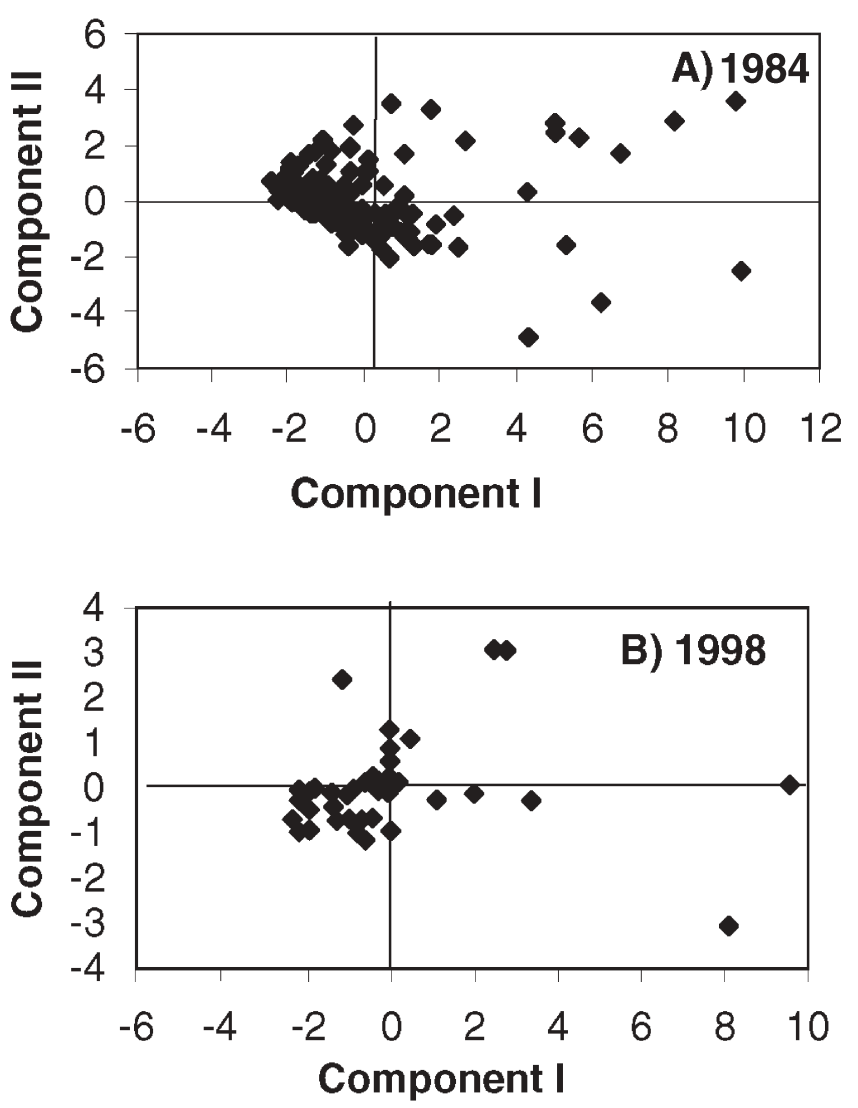

Fig. 12 Distribution of the samples in the principal components analysis with respect to the first two components; A 1984, B 1998

similar to 1984 (67.1 and $13.2 \%$, respectively). The spatial distribution of the variables according to the two first components is presented in Fig. 11B. These two components discriminate the different water types in a similar way to the previous sampling but here component $\mathrm{I}$ is influenced by the sodium ion (its weight is 0.9096 , while in 1984 it was 0.5235 ) which suggests a more dominant role of the regional flow zone in determining the groundwater chemistry.
The results obtained from the principal components analysis corroborate results of the cluster analysis.

Q-Mode. For the 1984 sampling program (Fig. 12 A), component I groups the water type of the samples based on their salinity, such that samples plotted away from this axis have high concentrations of nitrates and sulfates (superior quadrant) or sodium (inferior quadrant). For the 1998 sampling program (Fig. 12B), most samples are grouped close to the component I axis, which defines the principal chemical characteristic of the groundwater, namely its $\mathrm{Na}-\mathrm{Ca}$ bicarbonate facies. The samples that are distant from this axis are distinguished by their nitrate content (superior quadrant).

\section{Heavy metals}

Table 2 shows the $\mathrm{Al}, \mathrm{As}, \mathrm{Ba}, \mathrm{Cd}, \mathrm{Cu}$, total $\mathrm{Cr}, \mathrm{Hg}, \mathrm{Pb}$, $\mathrm{Fe}, \mathrm{Mn}, \mathrm{F}$ and $\mathrm{Zn}$ content of samples taken by CEAS in the 1993 and the 1997 sampling programs. The content of these elements is heterogeneous, but the Mexican limits for potable water (DOF 1994) are not exceeded, except for $\mathrm{Fe}$ and $\mathrm{Mn}$ (limits are 0.30 and $0.15 \mathrm{mg} \mathrm{L}^{-1}$, respectively).

The presence of all these ions is related to the volcanic rocks and derived materials of the area (Huizar-Alvarez 1997; Appelo and Postman 1993). In the case of Fe and $\mathrm{Mn}$, the possibility of an anthropic origin is not considered likely due to the fact that their concentrations are very low and seem not to be related to the presence of any other compound or chemical element that would indicate anthropic pollution.

\section{Conclusions and recommendations}

The water demands not only for urban, but also for agricultural and industrial uses in the Valle de Toluca, as well as in the Valle de Mexico, have led to intensive exploitation of the groundwater resources of the Valle de Toluca. The abstractions have depressed the water table in the aquifer, and produced land subsidence, as well as decreases or complete desiccation of river flows and springs.
Table 2 Statistical summary of heavy metals concentrations (1993 and 1997). Values in mg. $\mathrm{L}^{-1}$

\begin{tabular}{|c|c|c|c|c|c|c|c|c|c|}
\hline \multirow[t]{2}{*}{ Metals } & \multirow{2}{*}{$\begin{array}{l}\text { Permissible } \\
\text { levels for } \\
\text { drinking water }\end{array}$} & \multicolumn{4}{|l|}{1993} & \multicolumn{4}{|l|}{1997} \\
\hline & & Min & Max & Mean & S.D. & Min & Max & Mean & S.D. \\
\hline $\mathrm{Al}$ & 0.20 & & & & & 0.030 & 0.203 & 0.098 & 0.038 \\
\hline As & 0.05 & 0.001 & 0.007 & 0.004 & 0.004 & 0.004 & 0.051 & 0.026 & 0.015 \\
\hline $\mathrm{Ba}$ & 0.70 & 0.001 & 0.102 & 0.030 & 0.033 & 0.001 & 0.106 & 0.039 & 0.036 \\
\hline $\mathrm{Cd}$ & 0.005 & 0.001 & 0.006 & 0.003 & 0.002 & 0.001 & 0.003 & 0.001 & 0.001 \\
\hline $\mathrm{Cu}$ & 2.00 & 0.006 & 0.064 & 0.022 & 0.020 & 0.002 & 0.075 & 0.038 & 0.023 \\
\hline $\mathrm{Cr}$ Total & 0.05 & & & & & 0.012 & 0.030 & 0.021 & 0.007 \\
\hline $\mathrm{Hg}$ & 0.001 & & & & & 0.001 & 0.041 & 0.002 & 0.005 \\
\hline $\mathrm{Pb}$ & 0.025 & 0.004 & 0.009 & 0.007 & 0.004 & 0.002 & 0.018 & 0.008 & 0.005 \\
\hline $\mathrm{Fe}$ & 0.30 & 0.01 & 0.10 & 0.05 & 0.04 & 0.01 & 2.51 & 0.15 & 0.39 \\
\hline $\mathrm{Mn}$ & 0.15 & 0.01 & 0.13 & 0.05 & 0.05 & 0.01 & 0.22 & 0.03 & 0.04 \\
\hline $\mathrm{F}$ & 1.50 & 0.10 & 0.25 & 0.20 & 0.05 & 0.02 & 1.24 & 0.26 & 0.19 \\
\hline $\mathrm{Zn}$ & 5.00 & 0.010 & 0.999 & 0.129 & 0.326 & 0.004 & 0.168 & 0.047 & 0.045 \\
\hline
\end{tabular}

Min minimum, Max maximum, S.D. Standard Deviation 
This exploitation of the aquifer has also produced changes in the chemistry of the groundwater. Initially, groundwater in a local flow zone was exploited, originating from recharge of the aquifer by rainwater infiltration and from lateral flows from adjacent basalt and andesite fractured aquifers. This water is of the magnesium-bicarbonate type.

As time passed, and due to the decline of the watertable level, waters from a regional flow zone, linked to deep rhyolite formations, has been induced to enter to water wells. This regional flow is characterized by waters of the sodium-bicarbonate type, with a high potassium content, greater salinity and higher temperatures.

In parallel with this change in the salinity of the groundwater, an increase in the nitrate content has been detected, which is due to the use of fertilizers in agricultural areas and/or to the discharge of wastewater. High sulfate concentrations are also observed in the shallow boreholes, which are related to the use of ammonium sulfate fertilizers.

The statistical analysis has allowed a distinction of the different water types and a determination of which parameters characterize each type, which helped in establishing the origin of the water.

The overexploitation has not caused significant deterioration in the water quality of the aquifer, but a change in its chemical characteristics. An increase in the presence of certain contaminants such as nitrates and some heavy metals has been detected.

In view of this situation, it is necessary to define a groundwater quality monitoring network in order to instigate a monitoring program to record the spatial and temporal evolution of the main physico-chemical parameters that are indicators of change in the underlying water chemistry and of pollution processes. Among the parameters to monitor, $\mathrm{SiO}_{2}$ should be included to research the state of ionic balance of the water with respect to the geology of the aquifer.

Acknowledgments The authors would like to thank the CONACyT (Consejo Nacional de Ciencia y Tecnología de Mexico, Project 0391) and the Universidad Autónoma del Estado de México (Project 1067) for their financial support. Dr. J.M. Andreu is grateful to the University of Alicante for its support throughout a Research Fellowship. Field surveys were conducted with the assistance of the Comision Nacional del Agua (CNA)-Estado de México. The authors would also like to thank Dr. L. Vives and the referees for their helpful reviews.

\section{References}

APHA, AWWA, WEF (1995) Standard methods for the examination water and wastewater, 19th edn. APHA, AWWA \& WEF. Washington, D.C.

Appelo CAJ, Postman D (1993) Geochemistry groundwater and pollution. A.A. Balkema, Rotterdam

Ariel (1996) Estudio de simulación hidrodinámica y diseño óptimo de las redes de observación de los acuíferos de Calera, San Luis Potosí y Toluca [Study of the hydrodynamic modelling and optimum design of the observation network of the Calera, San
Luis Potosí and Toluca aquifers]. Technical Report Comisión Nacional del Agua. Gobierno Federal. México

Baretta GP, Pagotto A, Vandini R, Zanni S (1992) Aquifer overexploitation in the Po Plain: hydrogeological, geotechnical and hydrochemical aspects. In: Simmers I, Villaroya F, Rebollo LF (eds) Selected papers on aquifer overexploitation. Verlang Heinz Heise, Hannover 115-130

Birkle P, Torres-Rodriguez V, Gonzalez-Partida E (1998) The water balance for the Basin of the Valley of Mexico and implications for future water consumption. Hydrogeol J 6:500 517

Boehm B, Sandoval M (1999) La sed saciada de la Ciudad de México y la nueva cuenca Lerma-Chapala-Santiago. Un ensayo metodológico de lectura cartográfica [The quenched thirst of the Mexico City and the new Lerma-Chapala-Santiago basin. A methodological test of cartographic reading]. Relaciones. Estudios de Historia y Sociedad XX(80):15-68

Brown CE (1998) Applied multivariate statistics in geohydrology and related sciences. Springer, Berlin Heidelberg New York

CCRECRL Comisión Coordinadora para la Recuperación Ecológica de la Cuenca del Río Lerma (1993) Atlas Ecológico de la Cuenca Hidrográfica del río Lerma [Ecological atlas of the watershed of the Lerma River]. Gobierno del Estado de México, México

Custodio E (1992) Hydrogeological and hydrochemical aspects of aquifer overexploitation. In: Simmers I, Villaroya F, Rebollo LF (eds) Selected papers on aquifer overexploitation. Verlang Heinz Heise, Hannover pp 3-28

Custodio E, Llamas JR (1983) Hidrología Subterránea [Hydrogeology] 2nd edn. Omega, Barcelona

Davis JC (1986) Statistics and data analysis in geology, 2nd edn. Wiley, New York

Deman E, Mauvois T, Silva R (1976) El eje Neovolcánico Transmexicano [Transmexican Neovolcanic Axis]. In: Proceedings of Latin-American Congress of Geology. Instituto de Geología. UNAM, México

DGCOP Dirección General de Construcción y Operación Hidráulica (1984) Actividades Geohidrológicas en el Alto Lerma, México. [Hydrogeological activities in the Upper Catchment of the Lerma River, Mexico]. Technical Report Departamento del Distrito Federal. Ciudad de México. México

DOF Diario Oficial de la Federación (1994) NOM-127-SSA1-1994 Salud ambiental, agua para uso y consumo humano. Límites permisibles de calidad y tratamiento que debe someterse el agua para su potabilización. [Environmental health, water for human use and consumption. quality permissible limits and potabilization treatment] DOF 108-112, 15 de agosto de 1994

Esteller MV, Díaz-Delgado C (2002) Environmental effects of aquifer overexploitation: a case study in the Highlands of Mexico. Environ Manage 29(2)266-278

Golden Software Inc (1997) Surfer V. 6 Contouring and 3D surface mapping for scientists and engineers. User's Guide. Golden, Colorado

Herrera ME, Sánchez-Zavala JL (1994) Estratificación y Recursos Minerales del Estado de México [Stratigraphy and mineral resources in the State of Mexico]. Technical Report Secretaria de Desarrollo Económico. Gobierno del Estado de México, México

Honorio RJ, Hernández HF (1982) Origen, estratigrafía y petrología de la Cuenca de México y sierras circunvecinas. [Origin, stratigraphy and petrology of the Basin of Mexico and surrounding mountain ranges] Degree Dissert. Instituto Politécnico Nacional, México

Huizar-Alvarez R (1997) Hydrochemistry of the aquifers in the Rio Las Avenidas Basin, Pachuca, Hidalgo, Mexico. Water Air Soil Pollut 96:185-201

Martinelli G, Minissale G, Verrucgi C (1998) Geochemistry of heavily exploited aquifers in the Emiliana-Romagna Región (Po Valley, northern Italy). Environ Geol 36(3-4)195-206

Melloul A, Collin M (1992) The principal components statistical method as a complementary approach to geochemical methods 
in water quality factor identification; application to the coastal plain aquifer of Israel. J Hydrol 140:49-73

Morell I, Giménez E, Esteller MV (1996) Application of the principal components analysis to the study of salinization on the Castellon Plain (Spain). Sci Total Environ 177:161-171

Ritzi RW, Wright, SL, Mann B, Chen M (1993) Analysis of temporal variability in hydrogeochemical data used for multivariate analyses. Ground Water 31(2)221-229

SDA Secretaría de Desarrollo Agrícola. (1992) Estudio para el diagnóstico del acuífero del valle de Toluca para implementar la reglamentación de la extracción de agua subterránea.[Diagnostic study of the Valle de Toluca aquifer in order to imple- ment the groundwater exploitation regulations] Technical Report Gobierno Federal. México

Segovia N, Tamez E, Peña P, Carrillo J, Acosta E, Armieta MA, Iturbe JL (1999) Groundwater flow system in the valley of Toluca, Mexico: an assay of natural radionuclide specific activities. Appl Rad Isotopes 50(3)589-598

UNITECNIA (1996) Estudio para el diseño de redes de monitoreo de los acuíferos de los Valles de Toluca y Atlacomulco-Ixtlahuaca, en el Estado de México. [Study to design monitoring networks in the Toluca and Atlacomulco-Ixtlahuaca valley aquifers] Technical Report Comisión Nacional del Agua. Gobierno Federal, México 